\title{
IMPROVING READING COMPREHENSION OF THE TENTH GRADE OFFICE ADMINISTRATION STUDENTS OF SMK NEGERI 1 PINRANG BY USING EXPERIENCE-TEXT-RELATIONSHIP (ETR) METHOD
}

\author{
Fitriani. $S^{1}$, Nurhamdah ${ }^{2}$, Ismail Latif ${ }^{3}$ \\ Institut Agama Islam Negeri (IAIN) Parepare ${ }^{123}$ \\ fitrianifitti97@gmail.com ${ }^{1}$
}

\begin{abstract}
The objective of the research is to find out the improvement of the student's reading comprehension after the researcher applies Experience-Text-Relationship (ETR) Method at the tenth grade office administration students of SMK Negeri 1 Pinrang. The research design in this research was pre-experimental method with one group pre-test, treatment and post-test. The population in this research was the tenth grade students' office administration students of SMK Negeri 1 Pinrang consist of 105 students. The sample of this research was Class X Ap ${ }^{2}$ consist of 35 students. The researcher used purposive sampling because the teacher of SMK Negeri 1 Pinrang recommended this class. The researcher applies 30 items of multiple choice test. The result of this research indicated the students' mean score in pretest is 34.54 and mean score in post-test is 87.08. It can be concluded that the rate percentage in post-test was higher than the rate percentage in pre-test in teaching reading. This showed that Experience-Text-Relationship (ETR) method can improved students' reading comprehension. Based on the result finding, the t-test was greater than the value of t-table $(5.12 \geq 2.021)$. This showed that Experience-Text-relationship (ETR) Method can improve students' reading comprehension.
\end{abstract}

Keywords: Experience-Text-Relationship (ETR) Method, Reading Comprehension

\section{Introduction}

Reading is one of the language skills which is very important to be learned by students. Through this activity, students can improve their language and experience. They will get information and ideas which they need to know. Moreover, they will know what they do not know before.

A good reading will improve the student's ability in gathering ideas to communicate. However, sometimes the language learners have difficulties in reading comprehension. So, they have some problems in learning English, especially in reading comprehension. The problems faced by the students in reading comprehension are caused by the language. Learner's problem is usually in mastering vocabularies. English and 
Indonesian language are different, there is no guarantee that the students who have good understanding of Indonesian text will have good understanding of English text. That's why we need to do some method in teaching the reading comprehension.

Based on the researcher's experience in observing and interviewing the process of teaching and learning in SMK Negeri 1 Pinrang, there were some problems difficulties probably faced the students in reading activities such as, first the student's difficulties in decoding text. It causes them lack of motivation to learn reading finally their comprehension about reading are low. The second they were hardly to concentrate as they read and most of them are lazy to read the text. The next problem came from the teacher related to the methodology, the technique, the strategy of teaching reading used by the teacher. It is also found from the researcher observation, the students activity in reading were not very interesting because the teacher usually asked the students to do reading activity without clearly instructions.

Third, it is found that comprehend the text is also a serious problem for them. Students are failed to understand how sentences related to one another so, the students are not able to comprehend the text. Through the implementation of ETR Method especially in the step personal experiences related to text, the students' problem in class situation can be solved since their learning motivation in reading can be improved. Considering those benefits of ETR method, it is a method based on discussion to link what the reader already knows (experience) to what she or he encounters in the text. Furthermore, CristyDewiPramanik in her research about The Implementation of the Experience-TextRelationship (ETR) Method to Improve Grade Viii Students' Reading Comprehension at SMPN 9 Yogyakarta in the Academic Year of 2014/2015. The research findings show that there was an improvement in the students' reading comprehension after the experiencetext-relationship method was implemented in the teaching and learning process. It was indicated by the increasing mean scores of the students' pre-test and post-test results $(66,52$ to 77,41$)$.

Reading test is used to be a base together with the knowledge about the technique, theory, and evaluation of the teaching. The result of research can be used as an input in teaching learning process especially in teaching reading. Therefore the writer is interested 
in conducting a research entitled "Improving Reading Comprehension of the Tenth Grade Office Administration Students of SMK Negeri 1 Pinrang by Using Experience-TextRelationship (ETR) Method.

Based on the background above, the researcher formulates a problem statements as follow "Is Experience-Text-Relationship (ETR) Method able to improve Reading Comprehension at the tenth grade office administration students of SMK Negeri 1 Pinrang"

Based on the problem statement, the objective of the study are to find out The improvement of the student's reading comprehension after the researcher applies Experience-Text-Relationship (ETR) Method at the tenth grade office administration students of SMK Negeri 1 Pinrang.

JohariNur stated that in her research about The Effect of Using Experience Text Relationship (ETR) Method on Reading Comprehension of Recount text of the Second Year Students at Islamic Junior Boarding School DarelHikmahPekanbaru. The researcher found that there was significant effect of using Experience Text Relationship (ETR) method on Reading Comprehension of recount text of the second Year students at Islamic Junior Boarding School DarelHikmahPekanbaru, where tobserved shows 5.589 at significant level of 5\%, ttable shows 2.00 , and at level of $1 \%$, ttable shows 2.65 . Which shows $2.00<5.589>2.65$ In conclusion, using Experience Text Relationship (ETR) method has given a better effect for students reading comprehension of recount text of the second Year students at Islamic Junior Boarding School DarelHikmahPekanbaru.

Reading comprehension is the process of making meaning from text. The goal is to gain an overall understanding of what is described in the text to obtain meaning from words or sentences. In understanding read text information children developmental models or representations of meaning of the text ideas during the reading process. There are two classes of mental models: a text-based model, which is a mental representation of the propositions of the text and a situation model consisting of what the text is perceived to be about.

Reading comprehension is a complex, multiple task ability. These processes were divided into two equally difficult main types, lower-level, and higher-level processes. The 


\section{7nspiring: English Education Journal}

Volume I No 2 September2DI8

lower level abilities include word recognition, graph phonic and others, while the higherlevel abilities included syntactic, semantic and other processes.

The process of reading with comprehension appears to involve several essential and interrelated phases: (1) Information intake; focusing and attending to the pertinent environmental stimuli. (2) Fluency and vocabulary; associating the words on the page with stored knowledge to bring meaning to the text. (3) Patterning and networking; recognizing familiar patterns and encoding new information by linking it with prior knowledge.

Vocabulary building is a microcosm of the larger process of literacy building. Just as the brain's cortical processing at the early stages of learning to read is not the same as the cortical processing of the skilled reader, learning vocabulary building strategies modifies brain functions in systematic, predictable ways as enriched vocabulary becomes evident in reading comprehension, verbal language, and writing.

After a story has been read and discussed the vocabulary words can be contextualized as they were used in the story and then beyond. If a story used the word "ignore" students can be reminded that, "Bob ignored his mother's advice and climbed the tree" was a sentence from the book. Students can review the definition, and the word usage can be reinforced by questions that also use the word "ignore" and prompt the students to use it in their response. When asked, "Did you ever ignore anything?" students have answered from personal experience: "I ignore my baby brother when he screams" or "I ignore the telephone ringing when I don't want to talk to anybody." After a book is completed, students who finish other assignments early can take a word from the word list and create a page for it in the class dictionary of "Words We Know" including a preapproved definition, sentence, and illustration or drawing. Advanced word pages can include a listing of other definitions for the word and sample sentences for these alternative definitions.

Critical analysis is a careful examination and evaluation of a text, image, or other work or performance. Performing a critical analysis does not necessarily involve finding fault with a work. On the contrary, a thoughtful critical analysis may help us understand the interaction of the particular elements that contribute to a work's power and 


\section{7nspiring: English Education Dournal}

Volume I No 2 September2018

effectiveness.Learning to read and analyze texts in a critical way is generative of improvement in language proficiency as it helps learners to consider potential alternatives in language: to think of language as a system of choices.

Students learning grammar can simultaneously learn about the relationship between modality and authority, or about the connection between 'us' and 'them' pronouns and othering discourses, and they can learn to recognize who is a 'doer' and who is a 'done-to' when they are taught transitivity and voice. To the extent that such learning is brought to bear on a variety of texts and creative language activities, learners can increase their linguistic and pragmatic repertoire.

In any course involving text analysis, tools and methods of analysis could be fore grounded and the actual texts used considered less important. They could be reduced to the status of examples, used by teacher and students to demonstrate techniques of analysis at work. From the perspectives of critical pedagogy and culture learning, this would be a missed opportunity.

Writing and Deep Reading is thinking, and thinking tends to express itself in words, spoken or written. The marked book is usually the thought-through book. Finally, writing helps you remember the thoughts you had, or the thoughts the author expressed.The practice of deep reading is not a new idea in the world,but it is something that has fallen to the wayside with modern times and our society's obsession with procedural literacy over verbal literacy. We need new approaches that promote deep engagement with the world of ideas, and the implications of these ideas for a well-lived life. Multicultural education, in particular, can benefit from such pedagogical approaches.

Deep reading, the kind of reading encouraged by common core standards, asks students to "read like a detective" where they are looking closely for details. The think one reading is sufficient; they don't have the skills to uncover the craft, the complexities, and the nuances of the text. They can read and 'comprehend,' but they do so almost exclusively on a surface level. They miss much of the deeper beauty of the game. Deep reading forces students to dig further into the text by asking them to re-read, re-visit, and search for the hidden intricacies of the text. 
Based on the definitions above, it can be inferred that reading comprehension is a complex process in which a reader makes efforts to construct idea conveyed in a text. While the process of constructing idea, he or she employs the various reading abilities and connects his or her real-world knowledge with knowledge about language.

According to Kimbly and Garmezy in Brown describe that teaching is the activities to show or help someone to learn how to do something, give instructions, guide in the study of something, provide with the knowledge, cause to know, understand knowledge, and give new knowledge. Accordingly, teaching reading can be defined as the activity to facilitate students to achieve reading's goals by guiding students, giving instructions and providing them knowledge on how to read comprehensively.

Experience-Text-Relationship is a method of teaching that can be applied to improve reading comprehension. This method consisted of three systematic stages; those are experience stage, text stage and relationship stage. ETR is a method using discussion-based activity to relate what students already know or students' existing knowledge to what they are about to read. In this activity, a discussion refers to interactive communication between a teacher and students talking about a particular topic.

Carrell et al, that this experience-text-relationship (ETR) method emphasizes comprehension in reading for meaning. This ETR method can help the students to activate their background of knowledge in drawing the meaning of a text or story. Then, related it to the new information that they've got from the text after reading process.

Barbara says that in Experience Text Relationship (ETR) teachers begin to guide group discussions with a background building questions. What experience they had like then move to questions focusing on meaning construction from text and after reading, ask students to consider the relationship between their experiences and the ideas in the text.

Based on the definitions above, it can be inferred that the experience-text-relationship method provides discussion between a teacher and students expressing their background knowledge in relation to the text they are about to read in order to draw meaning for comprehension. 
The Experience-Text-Relationship (ETR) method consists of students expressing their own experience of knowledge about the topic prior to reading. After the students have adequately shared their knowledge, the text becomes the focus of the class. During this segment of the lesson, the teacher asks the students to read short sections of the text and then questions about the content. The teacher must be sensitive to those text areas that could elicit misunderstandings and work through any difficulties that the students may have. In the final stage, the teacher aids the students to draw relationships between personal experiences and the material discussed in the text stage. This provides an opportunity for each student to make comparisons and contrasts with what they already know and to accommodate the new information into their preexisting schemata. Through this process, student's schemata become redefined and extended. The teacher has the responsibility of leading the students to the appropriate answers without giving them too much information, so the task becomes one of self-discovery and integration.

The ETR involves three phases of discussion. In the first or Experience phase of discussion, the teacher has students discuss background experiences related to the theme she intends to develop for the story. In the Text phase of discussion, she uses questioning to guide students through the text, section by section, clarifying points unclear to students. Finally, in the Relationship phase, she guides students to draw relationships between the text and their own background experiences. The description of ETR lessons presented below focuses on picture story books.

ETR method has three basic steps. The three steps of ETR can be applied in classroom as follows: (1) Experience (E)for pre reading, have students discuss their personal experiences that relate to the theme, topic, or main idea of the text to be read. Then have students generate predictions about the story. (2) Text (T)While reading, either read the text aloud as the students follow along or allow students to read silently on their own. Read only one section of the story at a time. Discuss the section read and confirm and change predictions. Make sure that students tie their thoughts, comments, and predictions back to the text. Clarify any misconception or miscomprehension. Ask if there was any sections or words that were confusing and clarify these. Continue to alternate between 
reading and discussing small sections. (3) Relationship (R)For post reading, help students integrate the information from the text with their experiences to develop an understanding of the text.

K.H Au states that the way to promote reading achievement is the ETR (experience text relationship), it uses discussion to link what the reader already knows to what she or he will encounter in the text. It has essential steps: Experience, Text, and Relationship: (1) Experience (E) The teacher leads the students in discussion of their or knowledge or experiences that are related in some ways to the passage to be read. (2) Text (T)Students read the shorts parts of the texts, usually a page or two, and the teacher asking them questions about the content after each section is read. In this step, the teacher may also need to correct any misunderstanding of the text evidenced by the students. (3) Relationship (R)The teacher attempts to help the students draw relationship between the content of the text (as developed in the text step), and their outside experience and knowledge (as discussed in the experience text).

In $\mathrm{E}$ phase, the teacher asks the children questions design to elicit from them background knowledge which may be important to an understanding of the text. In T phase, the teacher has the children read the text, and the subsequent discussion that focuses on the ideas, present in the text. Finally, in phase R, the teacher tries to weave together the children's background knowledge and the information from the text.

\section{Method}

The research design was applied Pre-Experimental method by using pre-test, treatment, and post-test.The research did the research in SMK Negeri 1 Pinrang and researcher did research around one months because need several time to collect and analyze the data.The subject of this research is the Tenth grade office administration students of SMK Negeri 1 Pinrang academic year 2018/2019. There are three classes office administration in Tenth grade students of SMK Negeri 1 Pinrang namely $\mathrm{X} \mathrm{Ap}{ }^{1}, \mathrm{X} \mathrm{Ap}^{2}$, and $\mathrm{X} \mathrm{Ap}{ }^{3}$. The first is high level class, and the second until third are the middle level class. Consists of 105 students. The sample was taken by using purposive sampling because the 
teacher of SMK Negeri 1 Pinrang recommended this class. The researcher conducted in class X Ap ${ }^{2}$ of SMK Negeri 1 Pinrang, because it is the middle level further the students of this class are enjoyable than the other class. Class $\mathrm{X} \mathrm{Ap}{ }^{2}$ of SMK Negeri 1 Pinrang which consists of 35 students, 11 males and 24 females. There several reasons to pick this class at the sample, the varied of students ability might be the first reason. Furthermore, this research was conducted at office administration of SMK Negeri 1 Pinrang this school has sufficient facilitations to support teaching-learning activities. Each class consists of 35 students. In addition to the English teaching-learning process, this school also has a language laboratory.

The research applied reading text the instrument of data collecting for this research is reading test consisting pre-test and post-test. The pre-test is used to measure the basic ability of the students in reading while, the post-test used to measure the ability of the students in reading after giving the treatment. Therefore, the treatment which is used by the researcher is the Experience-Text-Relationship.The researcher used test for collecting data that are, reading test in pre-test and post-test. The pre-test was given to find out comprehend of the students before giving treatment, and post-test is used to find out the reading comprehension after giving treatment.All the data was collected, the data was tabulated, analyzed into percentage and classified into achievement category.

\section{Findings}

To know the improvement of students' reading comprehension by using ExperienceText-Relationship, the researcher calculated the mean score of the students' reading comprehension was indicated from two tests namely pre-test and post-test. The mean score in pre-test before treatment was 34.54 and the mean score of post-test was 87.08 after did the treatment.

\section{Discussions}

By looking at the test finding, as the result, the students found it easier to understand the content of the text and to obtain specific information from the text. It also enabled them to compare and contrast the result of the story with their prior prediction which led them to summary and make conclusion. The improvement of the students' reading comprehension 
was also supported by the result of reading test scores. Mostly the result of percentage in pre-test of Students (66\%) got Very Poor. While in post-test 35 Students (100\%) got Very Good, and none of them got Good, Fair, Poor, and Very Poor. It can be conclude that the students score in the post- test is higher than the rate percentage in the pre-test.

In addition, Experience-Text-Relationship (ETR) method helped the students to answer the question and make them understand the author argument. The student's score improve after using the treatment in reading. Before the treatment none the students got highest score classification, and after applied this method in reading there were 35 students got highest score classification. Thus, the alternative hypothesis $\left(\mathrm{H}_{1}\right)$ is accepted. The data above showed that the value of t-tes is 5.12 was greater than t-table value is 2.021 . It indicated that there was a significance difference between the result students' pre-tes and pos-test.

Based on the findings above, the researcher concluded that there was the ExperienceText-Relationship (ETR) method is able to improve the students reading comprehension at tenth grade office administration students of SMKNegeri 1 Pinrang by using Experience Text - Relationship(ETR) Method.

Experience Text Relationship is specifically designed to use children's experiences to teach new concepts and new words in the story. In this technique, the teacher spends time showing students the relationships between what they know and what they are reading, both before and after reading the story.

The Experience-Text-Relationship (ETR) method consists of students expressing their own experience of knowledge about the topic prior to reading. After the students have adequately shared their knowledge, the text becomes the focus of the class. During this segment of the lesson, the teacher asks the students to read short sections of the text and then questions about the content. The teacher must be sensitive to those text areas that could elicit misunderstandings and work through any difficulties that the students may have. In the final stage, the teacher aids the students to draw relationships between personal experiences and the material discussed in the text stage.

This provide an opportunity for each student to make comparisons and contrasts with what they already know and to accommodate the new information into their 
preexisting schemata. Through this process, student's schemata become redefined and extended. The teacher has the responsibility of leading the students to the appropriate answers without giving them too much information, so the task becomes one of selfdiscovery and integration. When researchers conducted the research in the class by giving tests to students, the difficulties that often arise such as students do not understood the meaning of the sentence that they read. Even though, the students know the steps of the Experience-Text-Relationship method, but they are difficult to read the text.

In the first test category students still have problem in identifying reading text although only 1 students answer fair. Some of them are still difficult to differentiate to find out main idea of reading text. In the second test categorystudents still have problem in identifying synonym and antonym of the reading text. Most of them still confused to distinguish among of the word,the students' do not find the moral value of the text and also, the students' do not know of the communicative purpose of the text. In the lastly categorystudents still have problem in answering the question. Most of them are difficult to find main idea and then choose the best answer.

After implementing Experience-Text-Relationship method in the classroom the students got sufficient practice in sharing their experience and background knowledge on their own group. Each student had a certain experience and background knowledge to be shared to other students. They do it on group to have the complete idea on the text. Based on schemata theory. Experience-Text-Relationship method really helpful for students before reading because this provide an opportunity for students to make comparison and contrast with what they already know and to accommodate the new information into their preexisting schemata. Through this process, students' schemata become redefined and extended.

The second part is Text, the students reading the short parts of the text, usually a page or two and the researcher ask them questions about the content after each section is read the text, either read the text aloud as the students follow along or allow students to read silently on their own, read only one section of the story at a time, discuss the section read, confirm and changed predictions and make sure that students tie their thought, comments, and predictions in the text. Based on the theory Experience-Text-relationship method really 
helpful the students after reading the text, because the students discuss the section read and changed prediction of the text what already know to accommodate the new information in the classroom through this process the students elicit misunderstanding and work through any difficulties that the student.

The last part is Relationship,The students integrate the information from the text with their experience to develop an understanding of the text. Every meeting the students know the steps of ETR method to practice their reading, it was hoped to attract the students ideas and inspiration when read a new story. The researcher also gives the students an opportunity to contrast and compare the information presented in the text with their existing knowledge. The data of the students score in the table 4.4 showed that there a changed of students score after did the treatment. All the sample of the research, 35 students got very good score, it means that on this relationship part the students were able to make contrast and comparison between their existing knowledge and the new story that they found on the text. The ETR method really helpful the students to attract after read a new story, this process provides the opportunity for students to expand their existing schemata.

Based on explanation above, the Experience-text-relationship method provides opportunities for students to explore many dimensions of the story and to integrated features of it with their existing of knowledge and the ETR method was help to stimulate the student's interest in reading and help to develop their comprehension. Since ETR method is a discussion based activity, it encourages students to think critically and to develop their way of thinking and also engages the entire class to interact and share their experience. ETR method was helpful the students to god reading active background know.

\section{Conclusion}

Based in the finding and discussion in the previous chapter, the researcher concluded the research result as follow:

There is a significant different between the students' in reading comprehension at the tenth grade office administration students of SMK Negeri 1 Pinrang before and after giving treatment. It is proven the mean score of pre-test that is 34.54 , then improved to 87,08 as the mean score of post-test. It means that quality of the students' in reading comprehension 
improved from "very poor" to "very good" after using Experience-Text-Relationship method in giving treatment. The use of Experience-Text-Relationship method is able to improve students' reading comprehension at the tenth grade office administration students of SMK Negeri 1 Pinrang. It is proven by the t-test value that is 5.12 which is higher than 2.021 as the t-table value.

Experience-Text-Relationship (ETR) method can be applied in English teaching learning process, particularly the attempt of improving reading comprehension by using Experience-Text-Relationship (ETR) method.

\section{Bibliography}

Alexander J. Estill, Teaching Reading. General Editor. (Little, Brown And Company Buston Toronto. 1979).

$\mathrm{Au}$ K. H., Using The Experience-Text-Relationship Method With Minority Children. Reading Teacher, 1979, 32 (6)

, Literacy instruction in multicultural settings. Orlando, FL: Harcourt Brace. (1993).

Brown H. Doughlash, principle of language learning and teaching fourth edition (san Franscisco: California, 2000)

, Teaching by principle: an active approach to language pedagogy (Toronto:

prencice hall)

,language assessment: principle and classroom practice (san Francisco:

California,2003)

DevineCarrell, J. and D. Eskey. 1989. Interactive Approaches to Second Language Reading. Cambridge University Press: Cambridge.

English Club, What is Reading?, http//www.englishclub.com/reading/what.htm (Accessed 14 February 2018).

G. Woolley, Reading Comprehension: Assisting Children with Learning Difficulties,( Springer Science +Business Media B.V. 2011)

Gay L.R., Educational Research Competencies For Analysis and Application, (pearson education ltd :Merril prentice Hall, 2006.

Grabe William, Teaching and Researching Reading, (Second edition published in Great Britain in 20 II by Pearson Education Limited, 2002) 
guzzeti Barbara J., Literacy In America an Encyclopedia of History, Theory and Practice.: [electronic version] http://library.nu/docs/R5XLTMW4BA/ Literacy\%20in\%20America.

Hall Maureen P.,The power of deep reading and mindful literacy:An innovative approach in contemporary (Education Berea College, Kentucky 2015)

Hall, Donald, "Four Kinds of Reading." Thinking in Writing 2nd ed Donald McQuade and Robert Atwan (New York: Knopf, 1983)

Iedunote, Reading Technique for increasing learning \& knowledge, http:// iedunote.com/reading-techniques ( Accessed 14 February 2018).

J. Deegan, Experience Text Relationship, (2007)

K12 Reader, What is Reading Comprehension?, http://www.k12reader.com/what-isreading-comprehension/ (Accessed 6 March 2018).

Mckee Steve, Reading Comprehension, what we know, (Shinawatra International University, Bangkok, Thailand 2012)

, Reading Comprehension, what we know , (Shinawatra International University, Bangkok, Thailand 2012)

Mensiresolusi, Teaching reading comprehension by using Experience-Text-Relationship strategy to the Eight Grade Students of SMP sandika Palembang (2012),

NordquistRichard, A Guide to Deep Reading, https://www.thoughtco.com/what-is-deepreading-1690373(accessed 3 May 2018)

Nunan David, Language Teaching Methodology.(New York : Prentice Hall international, 1991)

NurJohari on her research, The Effect of Using Experience Text Relationship (ETR) Method on Reading Comprehension of Recount text of the Second Year Students at Islamic Junior Boarding School DarelHikmahPekanbaru, (State Islamic University Of Sultan SyarifKasim Riau Pekanbaru,2013)

parvisAjideh, schema theory-based pre-reading tasks: a neglected essential In the esl reading class The Reading Matrix Vol.3. No.1,( April 2003

PermanikDewiCristy on her research, the implementation of the experience-textrelationship (etr) method to improve grade viii students' reading comprehension at smp n 9 yogyakarta in the academic year of 2014/2015. 
Prof. Dr.H.M. BurhanBungin,S.sos. ,M.Si, Metodologipenelitiankuantitatif :komunikasi, ekonimi, dankebijakan public sertailmu-ilmu social lainnya( Jakarta: kencana, 2008) , p.99.

Purnama Sari Juwita on her researcher, The Effect of Applying Experience Text Relationship Method on the Students' Reading Comprehension 2013

SekolahTinggi Agama Islam Negeri (STAIN), PedomanPenulisanKaryallmiah,(Parepare: STAIN Parepare, 2013)

Sinambela Erika, English Linguistics Research, Vol. 4, No. 3; 2015,P.15

Sugiono, MetodePenelitianPendidikan (PendekatanKuantitatif,Kualitatif,dan R\&D) ,(Bandung: Alfabeta,2014)

Suharsimi, Arikunto,Dasar-dasarEvaluasiPendidikan, EdisiRevisi;(Jakarta: Bumi Aksara,2009)

ThoughtCo, Critical Analysis, https://www.thoughtco.com/what-is-critical-analysiscomposition-1689810( accessed 28 march 2018)

Turn on your brain, Defining “Deep Reading" and "Text-Dependent Questions”https://turnonyourbrain.wordpress.com/2012/03/29/defining-deepreading-and-text-dependent-questions/ (Accessed 28 march 2018 )

Wharton Sue, Critical text analysis: lingking language and cultural studies, ELT journal volume 65/ 3 July 2011, (Published by oxford university press : all rights reserved.2010)

Wikipedia, Reading (Process), https://en.wikipedia.org/wiki/Reading_(process) (Accessed 5 March 2018).

, Reading comprehension, http://en.wikipedia.org/wiki/description (Accessed 5 March 2018

Willis Judy, M.D, Teaching the Brain to Read ( Production Manager, Marlene, Hachberg, Typesester, 2008)

Woolley G., Reading Comprehension: Assisting Children with Learning Difficulties,( Springer Science +Business Media B.V. 2011) 